\title{
Properties of textile and leather materials treated with new hybrid $\mathrm{SiO}_{2} / \mathrm{TiO}_{2} /$ poly $(2,2$ '-bithiophene) nanocomposites \\ DOI: $10.35530 / I T .070 .03 .1634$
}

\section{REZUMAT - ABSTRACT}

Proprietățile materialelor textile și din piele tratate cu noi nanocompozite hibride pe bază de $\mathrm{SiO}_{2} / \mathrm{TiO}_{2} /$ poli(2,2'-bitiofen)

Scopul acestui studiu a fost de a investiga influența nanocompozitelor noi pe bază de $\mathrm{SiO}_{2} / \mathrm{TiO}_{2} /$ poli(2 2'-bitiofen) cu concentrații diferite de nanoparticule de $\mathrm{TiO}_{2}$ și $\mathrm{SiO}_{2}$ asupra proprietăților de suprafață a țesăturii din $50 \%$ bumbac/50\% poliester si respectiv, pielii de ovină. Dispersiile realizate pe baza noilor nanocompozite au fost analizate în scopul determinării conductivității, dimensiunii particulelor, polidispersității și al potențialului Zeta. Materialele textile și din piele finisate au fost caracterizate din punctul de vedere al peformantei tratamentelor de functionalizare, prin: rezistivitatea de suprafață, comportarea la contactul cu apa, caracteristicile fizico-mecanice și proprietățile fotocatalitice. Microscopia electronică de baleiaj a fost utilizată pentru a investiga distribuția nanoparticulelor pe suprafața materialelor textile și din piele. Materialele textile tratate cu nanocompozitul hibrid pe bază de $\mathrm{SiO}_{2} /$ poli(2,2'-bitiofen) cu concentrație de $98 \% \mathrm{SiO}_{2}$ și, respectiv, pielea tratată cu $\mathrm{SiO}_{2}$ /poli(2,2'-bitiofen) cu concentrație de 95\% nanoparticule de $\mathrm{SiO}_{2}$ au prezentat valori ale rezistivității mai mici, confirmând astfel proprietățile conductive ale dioxidului de siliciu. Cea mai ridicată eficiență fotocatalitică a materialelor funcționalizate a fost obținută în cazul materialului textil tratat cu TiO_/poli(2,2'-bitiofen) cu concentratie de $95 \%$ nanoparticule de $\mathrm{TiO}_{2}$ și, respectiv, pentru pielea tratată cu $\mathrm{TiO}_{2} /$ poli(2,2'-bitiofen) cu concentrație de $98 \%$ nanoparticule de $\mathrm{TiO}_{2}$.

Cuvinte-cheie: nanocompozite hibride, nanocompozite pe bază de $\mathrm{TiO}_{2} / \mathrm{SiO}_{2} /$ poli(2,2'-bitiofen), rezistivitate de suprafață, proprietăți fotocatalitice, țesătură din $50 \%$ bumbac/50\% poliester, suprafață din piele

\section{Properties of cotton and leather materials treated with new hybrid $\mathrm{SiO}_{2} / \mathrm{TiO}_{2} /$ poly $\left(2,2^{\prime}\right.$-bithiophene $)$} nanocomposites

The aim of this study was to investigate the influence of new hybrid composites of $\mathrm{TiO}_{2}$ or $\mathrm{SiO}_{2}$ nanoparticles with poly(2,2'bithiophene) on $50 \%$ cotton $/ 50 \%$ polyester fabric and sheep skin leather surface properties. The dispersion-based newly made nanocomposites were analyzed to determine conductivity, particle size, polydispersity and Zeta potential. The finished textile and leather materials were characterized in terms of functionalization treatments performance by: surface resistivity, water contact behaviour, physical-mechanical characteristics and photocatalytic properties. SEM analysis was used to investigate the distribution of nanoparticles on the textile and leather materials surface. Textile materials treated with $\mathrm{SiO}_{2} /$ poly $\left(2,2^{2}\right.$-bithiophene) nanocomposite with concentration 98 wt\% nanoparticles of $\mathrm{SiO}_{2}$ and leather treated with poly $\mathrm{SiO}_{2}$ /poly(2,2'-bithiophene) nanocomposite with concentration of $95 \mathrm{wt} \%$ nanoparticles of $\mathrm{SiO}_{2}$ showed lower resistivity values, confirming the conductive properties of silica. The higher photodegradation efficiency of functionalized materials has been obtained for textile material treated with poly $\mathrm{TiO}_{2} /(2,2$ '-bithiophene)with concentration of 95 wt\% nanoparticles of $\mathrm{TiO}_{2}$ and for leather material treated with $\mathrm{TiO}_{2} /$ poly $(2,2$ '-bithiophene) with concentration of 98 wt\% nanoparticles of $\mathrm{TiO}_{2}$, respectively.

Keywords: hybrid nanocomposite, $\mathrm{TiO}_{2} / \mathrm{SiO}_{2} /$ poly(2,2'-bithiophene) nanocomposites, surface resistivity, photocatalytic properties, $50 \%$ cotton $/ 50 \%$ polyester fabric, leather surface

\section{INTRODUCTION}

Textile and leather material functionalization by using nanocomposites is a top research priority for smart finishing and multifunctional properties development [1-2]. Through synergic influence of polymers on nanomaterial composite, nanocomposites can add new properties such as: antibacterial [3], UV shielding, electrostatic charge dissipation, antistatic or conductive properties, water, oil, soil repellence, moisture management, flame retardancy, abrasion resistance, biocompatibility [4] etc. In the last years the use of conducting polymers [5-6] for flexible electronic textiles or leathers were studied and experimented using poly(3,4-ethylenedioxythiophene) [7], poly(fluorene), polyphenylene, polypyrene, polyazulene, polynaphthalene, poly(pyrrole) [8], polycarbazole, polyindole, polyazepine, polyaniline [9], poly(thiophene) [10-11], and poly(p-phenylene)sulphide in combination with metals (iron, cobalt, nickel, copper, palladium, silver, platinum, gold) or carbon based materials (graphite, carbon nanotubes, and carbon black). Traditional textiles, both natural and synthetic, and leather materials are almost always insulators. The interest in transforming them into conductors arises from the need to obtain antistatic or electromagnetic shielding garments, or for the production of the flexible electronic 
textiles or leather. Textile fibres including natural fibres and synthetic fibres are generally intrinsically nonconductive. Static charges are often formed in synthetic fibres, especially in dry environment. The static charges are generated by the motion of textile surfaces and during this process, negative charges are generated and accumulated on one surface and positive ones on the other surface. The negatively charged textile material has a stronger affinity for electrons that it steals from the other textile material after the two textile materials are separated. For textile materials synthetic fibres have more static problems compared with natural fibres. Hydrophilic chemical materials and moisture drastically decrease textile and leather resistivity with effect on static electric charges dissipation rate increase and conductive properties development for 95\% humidity [12].

There are few studies regarding the functionalization of textile and leather materials by using hybrid $\mathrm{TiO}_{2} /$ $\mathrm{SiO}_{2} /$ poly(2,2'-bithiophene) nanocomposites and the influence of treatment technologies on their surface properties. Multifunctional properties of fibrous material surfaces for daily and professional clothes and footwear are very important and offer the perspective of green solutions with competitive costs [13]. In our research we have investigated the influence of new hybrid nanocomposites of $\mathrm{SiO}_{2} / \mathrm{TiO}_{2} /$ poly(2,2'-bithiophene) on $50 \%$ cotton/ $50 \%$ polyester fabric and sheep skin leather surface properties. The aim of the investigations was the functionalisation of different fibrous materials in view of new added value products development. In this regard the surface resistivity, water contact behaviour, physico-mechanical characteristics and photocatalytic properties were investigated.

\section{EXPERIMENTAL}

\section{Materials}

For laboratory experiments the blended $50 \%$ cotton/ $50 \%$ polyester fabric with $218 \mathrm{~g} / \mathrm{m}^{2}$ and ecological sheepskin leathers processed in Leather Research Department have been used. Itobinder AG, an acrylic copolymer supplied from LJ Specialities (UK) has been used as binder in order to fix the polymeric nanocomposites on the surface of textile materials. Acrylic film forming polymers and nitrocellulose based emulsion purchased from SC Triderma SRL, were used for leather surface finishing.

Different $\mathrm{SiO}_{2} / \mathrm{TiO}_{2} /$ poly(2,2'-bithiophene) hybrid nanocomposites were prepared in INCDTFM' laboratories by making a microemulsion of dioctylsulfosuccinate sodium salt $\left(1.5 \times 10^{-3} \mathrm{~mol}\right)$ in $50 \mathrm{~mL}$ of $\mathrm{n}$-hexane to which were subsequently added: i) $\mathrm{FeCl}_{3}$ aqueous solution $\left(2 \times 10^{-2} \mathrm{~mol}\right.$ in $\left.1 \mathrm{~mL} \mathrm{H}_{2} \mathrm{O}\right)$; ii) various $\mathrm{SiO}_{2}$ or $\mathrm{TiO}_{2}$ nanoparticles quantities (0.5 and $1 \mathrm{~g})$ and iii) 2,2'-bithiophene $\left(2 \times 10^{-3} \mathrm{~mol}\right)$. This reaction mixture was homogenized by ultrasonication and mechanical agitation for 2 hours when red-violet precipitates were obtained. Then, these precipitates were washed with ethanol, filtered and dried until reaching constant mass. Dispersions of nanocomposites

\begin{tabular}{|c|c|}
\hline \multicolumn{2}{|c|}{$\begin{array}{l}\text { CODIFICATION OF NANOCOMPOSITES USED } \\
\text { FOR FUNCTIONALIZATION }\end{array}$} \\
\hline Nanocomposites & Codification \\
\hline $\begin{array}{l}\text { Poly (2,2'-bithiophene) with } 98 \% \text { wt } \% \\
\text { nano } \mathrm{SiO}_{2}\end{array}$ & PBTh-SiO $2 / 1$ \\
\hline $\begin{array}{l}\text { Poly (2,2'-bithiophene) with } 95 \% \text { wt\% } \\
\text { nano } \mathrm{SiO}_{2}\end{array}$ & PBTh-SiO $2 / 0.5$ \\
\hline $\begin{array}{l}\text { Poly }(2,2 \text { '-bithiophene) with } 98 \% \text { wt\% } \\
\text { nanoTiO }_{2}\end{array}$ & PBTh- $-\mathrm{TiO}_{2} / 1$ \\
\hline $\begin{array}{l}\text { Poly }(2,2 \text { '-bithiophene) with } 95 \% \text { wt } \% \\
\text { nano } \mathrm{TiO}_{2}\end{array}$ & $\mathrm{PBTh} \mathrm{TiO}_{2} / 0.5$ \\
\hline
\end{tabular}

presented in table 1 were prepared by 30 minutes ultrasound stirring of $2 \mathrm{mg}$ nanopowders in $10 \mathrm{~mL}$ ultrapure water.

\section{Functionalization treatments of textile and leather materials}

\section{Functionalization of textile materials}

Prior to functionalization treatments the textile fabrics were subjected to preliminary preparation by hot alkaline treatment and bleaching. The immobilization of nanocomposites dispersions on $50 \%$ cotton $/ 50 \%$ polyester fabrics was performed by padding on the laboratory padder, under the following conditions: 2 passes, 2 bar squeezing pressure. Drying and curing of textile materials was made on the drying/curing/ heat-setting/vaporization, model TFO/S $500 \mathrm{~mm}$ (ROACHES, UK). The samples codification, technological parameters and the composition of treatment baths are found in the table 2 . The aspect of

Table 2

\begin{tabular}{|c|c|c|}
\hline \multicolumn{3}{|c|}{$\begin{array}{c}\text { THE CODIFICATION OF EXPERIMENTAL VARIANTS FOR } \\
\text { TEXTILE MATERIALS, TECHNOLOGICAL PARAMETERS, } \\
\text { COMPOSITION OF THE TREATMENT BATHS }\end{array}$} \\
\hline Code & $\begin{array}{l}\text { Content of } \\
\text { treatment bath }\end{array}$ & $\begin{array}{l}\text { Technological } \\
\text { parameters }\end{array}$ \\
\hline $1 V_{1}$ & PBTh- $\mathrm{TiO}_{2} / 0.5$ & $\begin{array}{l}\text { 1. Padding; } \\
\text { 2. Drying: } 100^{\circ} \mathrm{C}, 120 \mathrm{~s}\end{array}$ \\
\hline $1 V_{2}$ & $\begin{array}{l}\mathrm{PBTh}-\mathrm{TiO}_{2} / 0.5 \\
20 \mathrm{~g} / \mathrm{L} \text { Itobinder AG }\end{array}$ & $\begin{array}{l}\text { 1. Padding; } \\
\text { 2. Drying: } 100^{\circ} \mathrm{C}, 120 \mathrm{~s} \text {; } \\
\text { 3. Curing: } 150^{\circ} \mathrm{C}, 240 \mathrm{~s}\end{array}$ \\
\hline $2 V_{1}$ & PBTh- $\mathrm{TiO}_{2} / 1$ & $\begin{array}{l}\text { 1. Padding; } \\
\text { 2. Drying: } 100^{\circ} \mathrm{C}, 120 \mathrm{~s}\end{array}$ \\
\hline $2 V_{2}$ & $\begin{array}{l}\mathrm{PBTh}-\mathrm{TiO}_{2} / 1 \\
20 \mathrm{~g} / \mathrm{L} \text { Itobinder AG }\end{array}$ & $\begin{array}{l}\text { 1. Padding; } \\
\text { 2. Drying: } 100^{\circ} \mathrm{C}, 120 \mathrm{~s} \text {; } \\
\text { 3. Curing: } 150^{\circ} \mathrm{C}, 240 \mathrm{~s}\end{array}$ \\
\hline $3 V_{1}$ & $\mathrm{PBTh} \mathrm{SiO}_{2} / 0.5$ & $\begin{array}{l}\text { 1. Padding; } \\
\text { 2. Drying: } 100^{\circ} \mathrm{C}, 120 \mathrm{~s}\end{array}$ \\
\hline $3 V_{2}$ & $\begin{array}{l}\mathrm{PBTh}-\mathrm{SiO}_{2} / 1 \\
20 \mathrm{~g} / \mathrm{L} \text { Itobinder AG }\end{array}$ & $\begin{array}{l}\text { 1. Padding; } \\
\text { 2. Drying: } 100^{\circ} \mathrm{C}, 120 \mathrm{~s} \text {; } \\
\text { 3. Curing: } 150^{\circ} \mathrm{C}, 240 \mathrm{~s}\end{array}$ \\
\hline $4 V_{1}$ & $\mathrm{PBTh} \mathrm{SiO}_{2} / 0.5$ & $\begin{array}{l}\text { 1. Padding; } \\
\text { 2. Drying: } 100^{\circ} \mathrm{C}, 120 \mathrm{~s} \text {; }\end{array}$ \\
\hline $4 V_{2}$ & $\begin{array}{l}\mathrm{PBTh}-\mathrm{SiO}_{2} / 1 \\
20 \mathrm{~g} / \mathrm{L} \text { Itobinder AG }\end{array}$ & $\begin{array}{l}\text { 1. Padding; } \\
\text { 2. Drying: } 100^{\circ} \mathrm{C}, 120 \mathrm{~s} \text {; } \\
\text { 3. Curing: } 150^{\circ} \mathrm{C}, 240 \mathrm{~s}\end{array}$ \\
\hline
\end{tabular}




\begin{tabular}{|c|c|c|c|c|c|}
\hline \multicolumn{2}{|c|}{$\begin{array}{l}\text { Material: } \\
\text { Crust ecological sheepskin }\end{array}$} & \multicolumn{4}{|c|}{$\begin{array}{c}\text { Finishing technology for samples: } \\
\text { Control, } \mathrm{PBTh}-\mathrm{SiO}_{2} / 1-\mathrm{L} 1 ; \mathrm{PBTh}_{-} \mathrm{SiO}_{2} / 1-\mathrm{L} 2 \\
\text { PBTh- } \mathrm{TiO}_{2} / 1-\mathrm{L} 3, \mathrm{PBTh}-\mathrm{TiO}_{2} / 0.5-\mathrm{L} 4\end{array}$} \\
\hline \multicolumn{6}{|c|}{ Color: yellow } \\
\hline \multirow{2}{*}{ No } & \multirow{2}{*}{$\begin{array}{l}\text { Materials for leather surface } \\
\text { finishing }\end{array}$} & \multicolumn{3}{|c|}{ Layer, mL/L } & \multirow{2}{*}{ Application } \\
\hline & & 1 & 2 & 3 & \\
\hline 1 & $\begin{array}{l}\text { Compact acrylic binder } \\
\text { Pigment paste } \\
\text { Water (Control) or nanocomposite } \\
\text { dispersions }(\mathrm{L} 1, \mathrm{~L} 2, \mathrm{~L} 3, \mathrm{~L} 4)\end{array}$ & $\begin{array}{l}250 \\
110 \\
640\end{array}$ & & & $\begin{array}{l}\text { Layer } 1 \text { : } \\
2 \times \text { sprays, free drying, } \\
\text { ironing at } 50^{\circ} \mathrm{C} \text { and } 100 \mathrm{~atm}\end{array}$ \\
\hline 2 & $\begin{array}{l}\text { Compact acrylic binder } \\
\text { Pigment paste } \\
\text { Water (Control) or nanocomposite } \\
\text { dispersions }(\mathrm{L} 1, \mathrm{~L} 2, \mathrm{~L} 3, \mathrm{~L} 4) \\
\end{array}$ & & $\begin{array}{l}250 \\
110 \\
640\end{array}$ & & $\begin{array}{c}\text { Layer } 2: \\
2 \times \text { sprays, free drying }\end{array}$ \\
\hline 3 & $\begin{array}{l}\text { Nitrocellulose based emulsion } \\
\text { Water (Control) or nanocomposite } \\
\text { dispersions (L1, L2, L3, L4) }\end{array}$ & & & $\begin{array}{l}700 \\
300\end{array}$ & $\begin{array}{l}\text { Layer 3: } \\
2 \times \text { sprays, free drying, } \\
\text { ironing at } 50^{\circ} \mathrm{C} \text { and } 100 \mathrm{~atm}\end{array}$ \\
\hline
\end{tabular}

functionalized textiles treated in different experimental variants is shown in figure $1, a$.

\section{Functionalization of leather materials}

Nanocomposite dispersions (table 1) based on $\mathrm{SiO}_{2} /$ $\mathrm{TiO}_{2} /$ poly(2,2'-bitiophene) were mixed by ultrasound for 10 minutes in acrylic film forming polymers for base coat layer and in nitrocellulose emulsion for top coat layer and they were applied by spraying in classical technology for leather surface finishing (table 3 ). The concentration of nanopowders on leather surface was of $0.04 \mathrm{mg} / \mathrm{cm}^{2}$. The new leather surfaces (L1, L2, L3 and L4) were smooth and comparable with classical treated leathers (figure $1, b$ ).

\section{Methods}

\section{Characterization of nanocomposite dispersions}

The characterisation of $\mathrm{SiO}_{2} / \mathrm{TiO}_{2} /$ poly $(2,2$ '-bitiophene) based nanocomposite dispersions was carried out for conductivity properties using a conductometer C1010 from Consort Belgium, with 1-100 $\mathrm{mS} / \mathrm{cm}$ scale and for particle size, polydispersity and Zeta potential characteristics with Zetasizer Nano-ZS from Malvern.

\section{Characterization of functionalized textile and leather materials}

\section{Physical-mechanical and physical-chemical} characteristics

The finished fabrics were characterized in terms of physical-mechanical characteristics, respectively: mass (SR EN 12127-2003), thickness (SR EN ISO 5084:2001), hydrophilicity by determining the wettability (drop test method according with SR 12751/ 1989 standard). Leather surfaces were characterized by water drop contact angle measurement (VGA Optima XE device), for abrasion resistance (SR EN ISO 13520-2003) and rubbing fastness (SR EN ISO 11640-2013).

\section{Scanning Electron Microscopy (SEM)}

The surface morphology of the treated samples was investigated by a FEI Quanta 200 Scanning Electron
Microscope with a GSED detector, at $8000 \times$ magnification and accelerating voltage of $12.5 \mathrm{kV}-20 \mathrm{kV}$. Surface resistivity measurement

Surface resistivity was measured according to SR EN 1149-1:2006 (EN 1149-1:2006) by using the ohmmeter PRS 801, with a potential difference of $100 \pm 5 \mathrm{~V}$ for $15 \pm 1 \mathrm{~s}$. Five measurements of the surface resistivity of each textile or leather sample were measured, and their average values were recorded.

\section{Photocatalytic properties}

Photocatalytic activity of treated samples was evaluated qualitatively by determining the photo degradation efficiency of methylene blue dye used as aqueous solution. Textile and leather materials treated with each type of nanocomposites were cut into $2 \times 2$ $\mathrm{cm}$ pieces and stained with $10 \mu \mathrm{l}$ of 15 ppm methylene blue solution. Subsequently, the samples have been subjected to visible irradiation with a halogen lamp $\left(500 \mathrm{~W}, 8 \mathrm{~mW} / \mathrm{cm}^{2}\right)$ for 30 minutes. Evaluation of the photocatalytic activity was performed by measuring the color difference of the irradiated samples compared with non-irradiated samples (reference). Color measurements were performed according to ISO 105 J03:2001, using the Datacolor ${ }^{\mathrm{TM}} 650$ Spectrophotometer (Datacolor, Switzerland) and the light source was the illuminant D65/10. Values obtained for chromatic parameters ( $D L^{*}$ - difference of lightness) are the average of 5 individual measurements carried out in different points on the same sample.

\section{RESULTS AND DISCUSSION}

\section{Nanocomposites characterisation}

The conductivity, particle size, polydispersity and Zeta potential of $\mathrm{SiO}_{2} / \mathrm{TiO}_{2} /$ poly(2,2'-bitiophene) based nanocomposite dispersions are presented in table 4 and show that the conductivity properties are similar with values from 18.7 to $22.2 \mu \mathrm{S} / \mathrm{cm}$ and the average particle sizes are lower for $\mathrm{PBTh}-\mathrm{TiO}_{2} / 1$ composite with best value for polydispersity. The most 


\begin{tabular}{|c|c|c|c|c|c|}
\hline \multicolumn{6}{|c|}{ NANOCOMPOSITE DISPERSIONS CHARACTERISATION } \\
\hline No. & Sample & $\begin{array}{c}\text { Conductivity } \\
(\mu \mathrm{S} / \mathrm{cm})\end{array}$ & $\begin{array}{l}\text { Average particle } \\
\text { size }(\mathrm{nm})\end{array}$ & $\begin{array}{c}\text { Polydispersity } \\
\text { PDI }\end{array}$ & $\begin{array}{c}\text { Zeta potential } \\
(\mathrm{mV})\end{array}$ \\
\hline 1 & PBTh- $\mathrm{TiO}_{2} / 0.5$ & 21.6 & 787.4 & 0.470 & -23.1 \\
\hline 2 & $\mathrm{PBTh}^{-\mathrm{TiO}_{2} / 1}$ & 22.2 & 297.2 & 0.230 & -24.8 \\
\hline 3 & PBTh-SiO $2 / 0.5$ & 19.4 & 708.9 & 0.455 & -30.8 \\
\hline 4 & $\mathrm{PBTh}_{-} \mathrm{SiO}_{2} / 1$ & 18.7 & 785.3 & 0.477 & -34.9 \\
\hline
\end{tabular}


Fig. 1. Ilustrations of functionalized samples: $a$ - textile materials; $b$ - leathers

stable dispersions were PBTh- $\mathrm{SiO}_{2} / 1$ and PBTh$\mathrm{SiO}_{2} / 0.5$ with Zeta potential of -34.8 to $-30.8 \mathrm{mV}$.

\section{Textile and leather materials characterisation}

Scanning Electron Microscopy analyses confirm the low concentration and good dispersion of nanoparticles on materials surfaces, with clusters of around $2 \mu \mathrm{m}$ (figure 2).

\section{Surface resistivity}

Surface resistivity measurements allowed the selection of nanocomposite and technology for textile and leather treatment in order to increase conductivity. Analyzing the obtained results for functionalized textile materials it can be observed that the sample treated with $\mathrm{PBTh}-\mathrm{SiO}_{2} / 1$ nanocomposite and Itobinder $A G$ (code $3 V_{2}$ ) has the lowest resistivity (figure $3, a$ ). Leather surface shows lowest resistivity when is treated with $\mathrm{PBTh}-\mathrm{SiO}_{2} / 0.5$ nanocomposite (figure $3, b$ ), confirming the conductive properties of silica for both materials. The results showed lower resistivity values for textiles $\left(3 \mathrm{~V}_{2}\right)$ as compared to leather surface (L2). If we compare with literature data which show that the electrical resistivity of leather is lower by more than two orders of magni tude $\left(10^{2} \Omega\right)$ than of textile [12], we can conclude that the treatment with new nanocomposites makes the two materials similar in terms of electric properties.

Physical-mechanical and physical-chemical characteristics

\section{Hydrophilicity}

Water affinity of textile and leather treated surfaces was evaluated and showed no modification for textile materials and hydrophobic properties development on treated leather surface. In the case of textile materials the hydrophilicity does not show significant

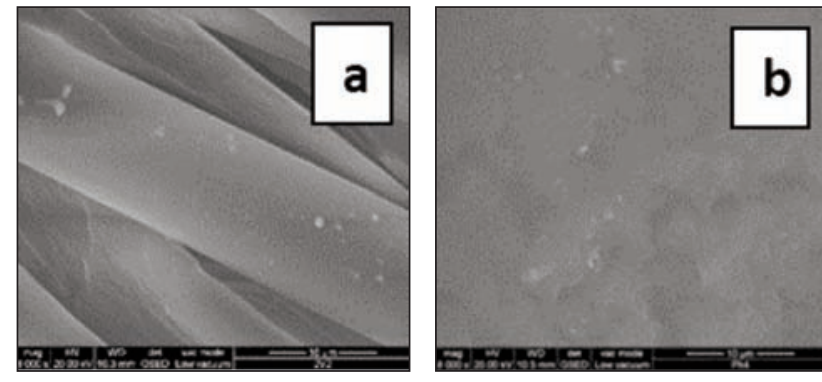

Fig. 2. SEM image at $8000 \times$ magnification for: $a$ - textile material, $b$ - leather material
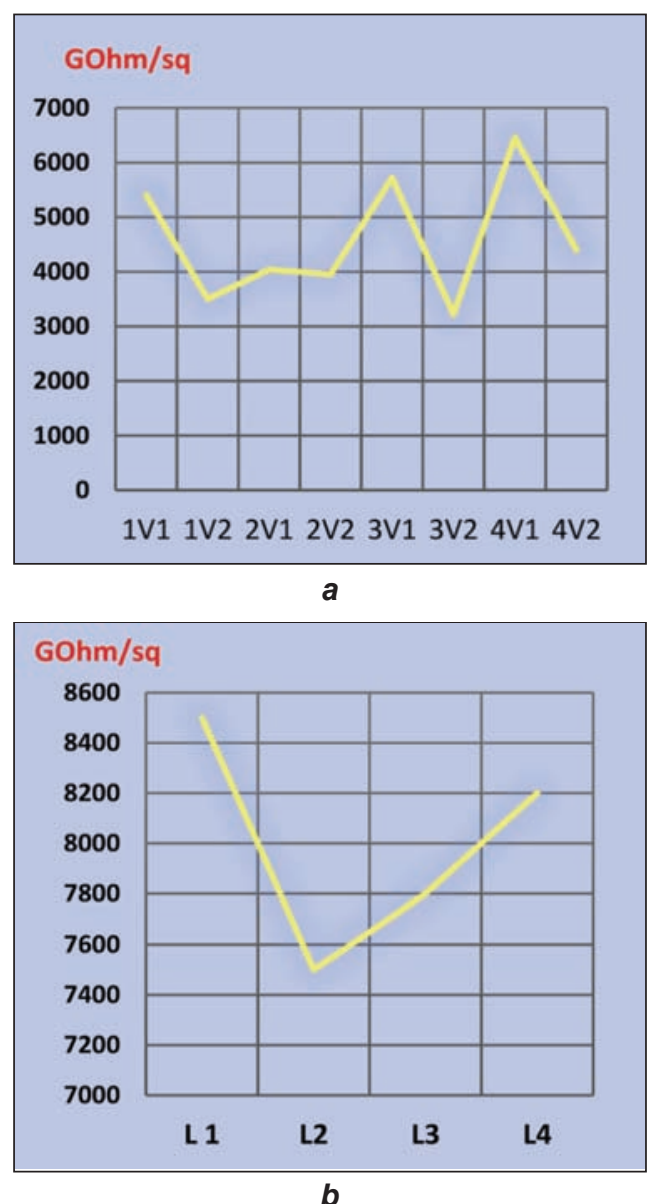

Fig. 3. Surface resistivity for: $a$ - textile materials, $b$ - leathers

changes after finishing treatments, just small variations (decreases) in compared to the untreated fabric, but these variations can be considered negligible. In the case of textiles samples, slightly lower values 
Table 5

PHYSICAL-MECANICAL AND PHYSICAL-CHEMICAL CHARACTERISTICS

\begin{tabular}{|c|c|c|c|}
\hline Sample & $\begin{array}{c}\text { Mass } \\
\left(\mathbf{g} / \mathbf{m}^{\mathbf{2}}\right)\end{array}$ & $\begin{array}{c}\text { Thickness } \\
(\mathbf{m m})\end{array}$ & $\begin{array}{c}\text { Hydrophilicity } \\
\mathbf{( s )}\end{array}$ \\
\hline 1V1 & 229 & 0.522 & $3-4$ \\
\hline 1V2 & 244 & 0.560 & 5 \\
\hline 2V1 & 220 & 0.490 & $3-4$ \\
\hline 2V2 & 243 & 0.530 & 5 \\
\hline 3V1 & 220 & 0.490 & $3-4$ \\
\hline 3V2 & 237 & 0.547 & 5 \\
\hline 4V1 & 230 & 0.480 & $3-4$ \\
\hline 4V2 & 243 & 0.528 & 5 \\
\hline M & 218 & 0.495 & 4 \\
\hline
\end{tabular}

of hydrophilicity are obtained for the fabrics treated in concomitant phase with dispersions based on PBTh- $\mathrm{TiO}_{2}$ or PBTh-SiO ${ }_{2}$ nanocomposites and with Itobinder AG, for which a wettability of 5 seconds has been obtained (table 5).

The modification of water drop contact angle on leather surface, from $48.1^{\circ}$ for classical finished leather to $90.5^{\circ}$ for $\mathrm{L} 2$ sample, $95.4^{\circ}$ for $\mathrm{L} 1,99.6^{\circ}$ for $\mathrm{L} 3$ and $105.5^{\circ}$ for L4 shows that hydrophobic properties can be developed by the treatment with new hybrid nanocomposites.

\section{Mechanical properties}

Analyzing the results obtained for $50 \%$ cotton $/ 50 \%$ polyester fabric treated in different variants with $\mathrm{PBTh}-\mathrm{TiO}_{2}$ or $\mathrm{PBTh}-\mathrm{SiO}_{2}$ nanocomposites (table 5), it can be observed that, during the finishing process, fabric contraction took place, leading to the increasing of mass $\left(\mathrm{g} / \mathrm{m}^{2}\right)$ and thickness $(\mathrm{mm})$ compared to the untreated fabric $(\mathrm{M})$, without significant differences between variants. This behaviour is normal for the finishing processes of cotton or blended fabrics carried out in aqueous medium and high temperatures. Also, the increase of these characteristics can also be caused by the additions of functionalization agents (nanocomposites and binder) that remain attached to the textile fabrics at the end of the process.

The abrasion resistances of $L 2, L 3$ and $L 4$ leather surfaces treated with new nanocomposites were good up to 51,200 revolutions as compared to the classical finished leather and L1 surface with resistances up to 25,600 revolutions. The rubbing test results showed good results up to 75 dry and wet rubbing cycles and up to 50 rubbing cycles with perspiration solution for sample L2 as compared to control and L1, L3 and L4 samples with lower performances.

\section{Photocatalytic properties of treated textile and leather surfaces}

Photocatalytic properties of textile materials have been assessed only for the samples treated with $\mathrm{PBTh}-\mathrm{TiO}_{2}$ nanocomposites. Photodegradation efficiency of functionalized textile materials stained with methylene blue solution varies depending on the quantity of $\mathrm{TiO}_{2}$ nanoparticles from nanocomposite dispersions, the best self-cleaning properties being obtained for sample treated with dispersion based on PBTh- $\mathrm{TiO}_{2} / 0.5\left(1 \mathrm{~V}_{1}\right)$ after 30 minutes of irradiation, the value of the lightness difference $\left(\mathrm{DL}^{*}\right)$ obtained for this sample having positive values, higher with 3 absolute units in comparison with the non-irradiated sample (figure 4,a).

Leather surfaces showed photocatalytic properties (figure $4, b$ ) with greater rates of organic stain decomposition than $119 \%$ (12.8 absolute units) for leather surface treated with $\mathrm{PBTh}-\mathrm{TiO}_{2} / 1$ (L3) and of $80.6 \%$ (10.7 absolute units) for leather treated with PBTh$\mathrm{SiO}_{2} / 0.5$ (L2), after 30 minutes of exposure to visible light, as compared to classical finished leather surface.
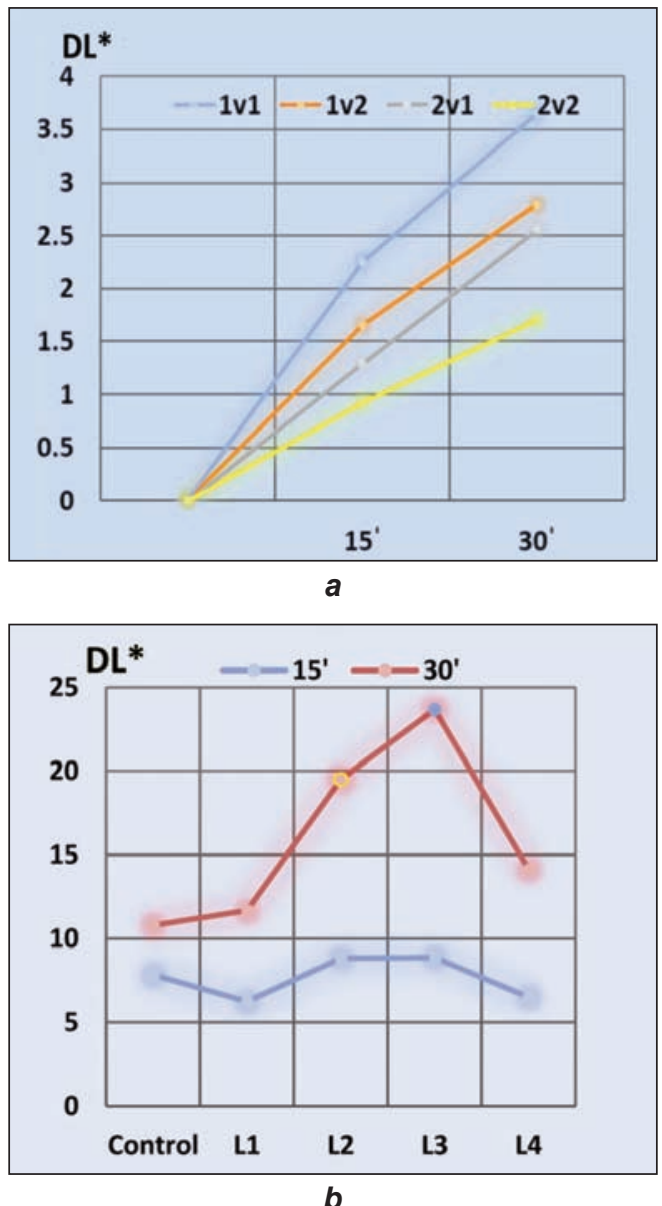

Fig. 4. Photocatalytic properties of: $a$ - textile materials, $b$ - leather surfaces

\section{CONCLUSIONS}

New hybrid $\mathrm{SiO}_{2} / \mathrm{TiO}_{2} /$ poly(2,2'-bitiophene) based nanocomposites with two concentrations of $\mathrm{TiO}_{2}$ and $\mathrm{SiO}_{2}$ nanoparticles were used for $50 \%$ cotton/50\% polyester fabrics and sheep skin leather treatment in view of multifunctional surface properties development. Textile materials treated with dispersion based on PBTh-SiO $/ 1$ nanocomposite and Itobinder AG showed lower resistivity. Mechanical properties of functionalized textile materials do not show significant changes after finishing treatments as compared 
to untreated fabric. The cotton/polyester fabric treated with $\mathrm{PBTh}-\mathrm{TiO}_{2} / 0.5$ nanocomposite showed a higher photodegradation stain efficiency.

Leather surface finished with $\mathrm{PBTh}-\mathrm{SiO}_{2} / 0.5$ nanocomposite showed lowest resistivity as compared to other nanocomposites, hydrophobic and photocatalytic properties in visible light against methylene blue stain. Leather surface treated with PBTh- $\mathrm{TiO}_{2} / 1$ nanocomposite revealed more hydrophobic characteristics and best photocatalytic rate of methylene blue stain decomposition. The research on the potential of new hybrid nanocomposites based on $\mathrm{SiO}_{2} / \mathrm{TiO}_{2} /$ poly(2,2'-bitiophene) for multifunctional properties development on textile materials and leather surfaces is in progress.

\section{ACKNOWLEDGEMENTS}

This work was supported by a grant of the Romanian Ministry of Research and Innovation, CCCDI - UEFISCDI, project number PN-III-P1-1.2-PCCDI-2017-0743/ contract 44/2018, Project 3, within PNCDI III.

\section{BIBLIOGRAPHY}

[1] Gashti, M.P., Pakdel, E., Alimohammadi, F. Nanotechnology-based coating techniques for smart textiles, In: Active Coatings for Smart Textiles, 2016, pp. 243-268.

[2] Kaygusuz, M. K., Meyer, M., Aslan, A. The effect of $\mathrm{TiO}_{2}-\mathrm{SiO}_{2}$ nanocomposite on the performance characteristics of leather, In: Materials Research, 2017, vol. 20, no 4, pp. 1103-1110.

[3] Maestre-López, M.I., Payà-Nohales, F., Cuesta-Garrote, N., Arán-Ais, F., Martínez-Sánchez, M.A., Orgilés-Barceló, C., Bertazzo, M. Antimicrobial effect of coated leather based on silver nanoparticles and nanocomposites: synthesis, characterisation and microbiological evaluation, In: Journal of Biotechnology \& Biomaterials, 2015, vol. 5, pp. 171-181.

[4] Gowri, S., Almeida, L., Amorim, T., Carneiro, N., Souto, A. P., Esteves, M. F. Polymer nanocomposites for multifunctional finishing of textiles - a review, In: Textile Research Journal, 2010, vol. 80, pp. 1290-1306.

[5] O'Leary, D. Conductive leather materials and methods for making the same, US 8,507,102 B1, 2013, pp. 1-11.

[6] Baibarac, M., Baltog, L., Lefrant, S. Raman spectroscopic evidence for interfacial interactions in poly(bithiophene)/single-walled carbon nanotube composites, In: Carbon, 2009, vol. 47, pp. 1389-1398.

[7] Akerfeldt, M., Straat, Walkenstrom, P. Electrically conductive textile coating with a PEDOT-PSS dispersion and a polyurethane binder, In: Textile Research Journal, 2013, vol. 83, no 6, pp. 618-627.

[8] Wegene, J.D., Thanikaivelan, P. Conducting leathers for smart product applications, In: Industrial\&Engineering Chemistry Research, 2014, vol. 53, pp. 18209-18215.

[9] Erdogan, M.K., Karakisla, M., Sacak, M. Conductive polyaniline-polythiophene/poly(ethylene terephthalate) composite fiber: effects of $\mathrm{pH}$ and washing processes on surface resistivity, In: Journal of Applied Polymer Science, 2015, vol. 132, no 20, pp. 41979-41988.

[10] Dashti, M., Mokhtari, J., Nouri, M., Shirini, F. Imparting conductivity and chromic behavior on polyester fibers by means of poly(3-methylthiophene) nanocoating, In: Journal of Applied Polymer Science, 2011, vol. 124, no 4, pp. 3007-3012.

[11] Erdogan, M.K., Karakisla, M., Sacak, M. Preparation, characterization and electromagnetic shielding effectiveness of conductive polythiophene/poly(ethylene terephthalate) composite fibers, In: Journal of Macromolecular Science Part A-Pure And Applied Chemistry, 2012, vol. 49, no 6, pp. 473-482.

[12] Jankauskaitè, V., Gulbinienè, A., Kondratas, A., Domskienè, J., Urbelis, V. Influence of the structure of footwear upper and lining materials on their electrical properties, In: Fibres\&Textiles in Eastern Europe, 2018, vol. 26, pp. 7-92.

[13] Yuce, I., Yukseloglu, M., Canoglu, S. An analysis of conductive fibers as smart textiles, In: Annals of the University of Oradea. Fascicle of Textiles, Leatherwork, 2018, vol. 19, no 2, pp. 105-110.

\section{Authors:}

\section{LAURA CHIRILA ${ }^{1}$, CARMEN GAIDAU ${ }^{2}$, MALVINA STROE ${ }^{3}$, MIHAELA BAIBARAC ${ }^{3}$, MARIA STANCA ${ }^{2}$, DENISA MARIA RĂDULESCU ${ }^{1}$, DIANA ELENA RĂDULESCU ${ }^{1}$, COSMIN-ANDREI ALEXE $^{2}$}

${ }^{1}$ The Research-Development National Institute for Textile and Leather, 16, Lucretiu Patrascanu Street, Bucharest, 030508, Romania

${ }^{2}$ The Research-Development National Institute for Textile and Leather, Leather and Footwear Research Institute (ICPI) Division, 93, Ion Minulescu Street, Bucharest, 031215, Romania

${ }^{3}$ National Institute of Materials Physics - Romania Atomistilor Street 405 A, barac@infim.ro

\section{Corresponding author:}

\section{LAURA CHIRILA}

e-mail: laura.chirila@certex.ro

CARMEN GAIDAU

e-mail: carmen_gaidau@hotmail.com 